\title{
Vegetation of the eastern communal conservancies in Namibia: II. Environmental drivers
}

\begin{tabular}{|c|c|}
\hline \multicolumn{2}{|c|}{$\begin{array}{l}\text { Authors: } \\
\text { Ben J. Strohbach }{ }^{1} \\
\text { Josephat T. Kutuahuripa }^{2}\end{array}$} \\
\hline \multicolumn{2}{|c|}{$\begin{array}{l}\text { Affiliations: } \\
{ }^{1} \text { School of Natural Resources } \\
\text { and Spatial Sciences, } \\
\text { Polytechnic of Namibia, } \\
\text { Namibia }\end{array}$} \\
\hline \multicolumn{2}{|c|}{$\begin{array}{l}{ }^{2} \text { Plant Production Research, } \\
\text { Ministry of Agriculture, } \\
\text { Water and Forestry, Namibia }\end{array}$} \\
\hline \multicolumn{2}{|c|}{$\begin{array}{l}\text { Correspondence to: } \\
\text { Ben Strohbach }\end{array}$} \\
\hline \multicolumn{2}{|c|}{$\begin{array}{l}\text { Email: } \\
\text { bstrohbach@polytechnic. } \\
\text { edu.na }\end{array}$} \\
\hline \multicolumn{2}{|c|}{$\begin{array}{l}\text { Postal address: } \\
\text { Private Bag 13388, } \\
\text { Windhoek, Namibia }\end{array}$} \\
\hline \multicolumn{2}{|c|}{$\begin{array}{l}\text { Dates: } \\
\text { Received: } 30 \text { Oct. } 2012 \\
\text { Accepted: } 26 \text { Aug. } 2014 \\
\text { Published: } 28 \text { Nov. } 2014\end{array}$} \\
\hline \multicolumn{2}{|c|}{$\begin{array}{l}\text { How to cite this article: } \\
\text { Strohbach, B.J. \& } \\
\text { Kutuahuripa, J.T., 2014, } \\
\text { 'Vegetation of the eastern } \\
\text { communal conservancies in } \\
\text { Namibia: II. Environmental } \\
\text { drivers', Koedoe 56(1), Art. } \\
\text { \#1117, } 12 \text { pages. http:// } \\
\text { dx.doi.org/10.4102/koedoe. } \\
\text { v56i1.1117 }\end{array}$} \\
\hline \multicolumn{2}{|c|}{$\begin{array}{l}\text { Note: } \\
\text { Additional supporting } \\
\text { information may be found } \\
\text { in the online version of } \\
\text { this article as an Online } \\
\text { Appendix: http://dx.doi. } \\
\text { org/10.4102/koedoe. } \\
\text { v56i1.1117-1. }\end{array}$} \\
\hline \multicolumn{2}{|l|}{ Read online: } \\
\hline 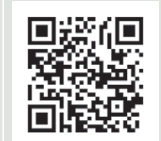 & $\begin{array}{l}\text { Scan this QR } \\
\text { code with your } \\
\text { smart phone or } \\
\text { mobile device } \\
\text { to read online. }\end{array}$ \\
\hline
\end{tabular}

The eastern communal conservancies are situated along the western fringe of the Kalahari basin. Under a very short rainfall gradient, the vegetation abruptly changes from microphyllous Acacia-dominated savannas to mesophyll savannas, dominated by Terminalia sericea and Combretum spp. We hypothesise that this is caused by changes in soil moisture availability brought about by changes in soil texture from loamy soils to deep sands (the 'inverse texture effect'). For this analysis, we used vegetation and soils data derived from a recognisance survey of the natural resources of the study area. As the sites in the soil and vegetation surveys did not overlap, it was decided to use only synoptic data for the plant associations in the analysis. Non-metric multidimesional scaling ordination was utilised as ordination technique of the vegetation data and various environmental parameters, including soil texture, soil hydraulic parameters, climatic and fire regime parameters, were overlaid as biplots onto the resulting graph, as were various plant functional attributes particularly related to climatic conditions. The main environmental gradient identified within the study area is the rainfall gradient. This relatively short gradient, however, does not explain the marked change in vegetation observed within the study area. This change is attributed to the change in soil type, in particular, the soil texture and the associated soil hydraulic parameters of the soil. This gradient is closely correlated to leaf size, explaining the change from microphyll savannas to mesophyll savannas along the change from loamy to sandy soils. One of the lesser understood mechanisms for the survival of these mesophyll plants on sandy soils seems to be a deep root system, which is actively involved in water redistribution within the soil profile - by hydraulic lift, inverse hydraulic lift and stem flow.

Conservation implications: Understanding these mechanisms will greatly assist in understanding savanna dynamics. With the threat of global climate change, we postulate that the vegetation will gradually change from the present mesophyll to a microphyll savanna, but that the grass sward will probably not develop very well. Shrub and tree removal ('bush harvesting') is likely to speed up the desertification process within this area.

\section{Introduction}

In the first article of this series (Strohbach 2014), the vegetation of eight communal conservancies, as well as two farming areas in east-central Namibia, are described. These conservancies are situated within the Camelthorn savanna in the south and the Tree savanna and woodlands described by Giess (1998) in the north. Here, under similar climatic conditions, the vegetation abruptly changes from a microphyll, Acacia-dominated savanna to a mesophyll savanna dominated by Terminalia sericea and various Combretum species, as the soils change from relative fine-grained soils of the central plateau to deep, coarse sands of the Kalahari basin (Leser 1972).

On an aridity gradient stretching over roughly $1100 \mathrm{~km}$ from north-northwest to south-southwest within the Kalahari Desert of Botswana (on uniformly sandy soils), macrophyllous trees are gradually replaced by microphyllous trees as the rainfall decreases and the aridity increases (Skarpe 1996). This rainfall gradient is estimated to range from $600 \mathrm{~mm}$ in the north-northeast to less than $250 \mathrm{~mm}$ in the south-southwest. On a similar aridity gradient from the Lesotho highlands to the west coast of southern Africa (with a rainfall gradient between $522 \mathrm{~mm}$ and $41 \mathrm{~mm}$ per annum), macrophyll plants were replaced by microphyll plants within a riverine forest as aridity increased (Werger \& Ellenbroek 1978). In the same study, an increasing number of plants with sclerophyllous leaves (as adaptations to arid conditions) were found in the more arid environments. More abrupt changes in the composition of moist savannas of central Mozambique (ranging from grasslands to savannas, to woodlands, forests and swamp forests) have, in detail, been demonstrated by Tinley (1982) to be related to differences in soil profiles, especially with regard to soil texture, soil depth and the presence and depth of constricting layers within the profile, despite a uniform climate. 
However, little is known on the causes for the abrupt change from microphyll to macrophyll savannas in the arid western Kalahari basin region.

Water availability is the main driving force of vegetation in arid environments (Noy-Meir 1973; Tinley 1982; Walter \& Breckle 1984). Tree roots are known to utilise an expansive soil volume to source nutrients and water. Record depths of $60 \mathrm{~m}$ and $68 \mathrm{~m}$ have been documented for Acacia erioloba and Boscia albitrunca, respectively, in the Kalahari (Canadell et al. 1996). Pterocarpus angolensis tree roots reach a depth of between $15 \mathrm{~m}$ and $20 \mathrm{~m}$ (Mwitwa, Munthali \& Van Wyk 2008), whilst Baphia massaiensis subsp. obovata has been reported to have a rooting depth of about $2.5 \mathrm{~m}-2.7 \mathrm{~m}$ (Savory 1963). Terminalia sericea, one of the most abundant species in the study area, is known to have a shallow root system less than $1 \mathrm{~m}$ deep under arid conditions (350 $\mathrm{mm}$ mean annual rainfall) (Hipondoka \& Versfeld 2006; Hipondoka et al. 2003). Under more mesic conditions (450 $\mathrm{mm}$ mean annual rainfall), however, this species tends to retain its tap root, reaching beyond the explored depth of $1.2 \mathrm{~m}$. Similar findings are known also from the Banksia woodlands in Australia, where some deep-rooted species obtain their water from a depth of up to $9 \mathrm{~m}$. Other evidence from Australian Eucalyptus savannas suggest that deep-rooting species are better capable of surviving drought conditions than shallow-rooting species (Fensham \& Fairfax 2009).

It is generally assumed that fine-textured soils have greater porosity, and thus a greater water-holding capacity, than coarse-textured (sandy) soils (Brady \& Weil 2002). Finer soils have a larger pore volume, albeit smaller pores, allowing more water to be stored in the profile. Added to this is the fact that water flows faster through larger pores - a sandy soil loses water to deep soil layers more rapidly than a loamy or clay soil. In arid and semi-arid areas, however, the inverse texture effect is observed - vegetation is lusher and better developed, often with a higher net primary productivity, on sandy soils than on finer clay or silt soils (Austin et al. 2004; Noy-Meir 1973). This is a result of the fact that soil water is held by adhesion to the fine-grained particles and is, in effect, not available to plants. In sandy soils, water infiltrates to deeper soil layers during the rainy season, out of reach of fast-growing, shallow-rooted plants such as grasses. During the dry season, this deep soil moisture reservoir becomes available to deep-rooted plants (Brady \& Weil 2002; NoyMeir 1973; Walter \& Breckle 1984). An in-depth analysis of this phenomenon has been provided by Laio, Porporato, Fernandez-Illescas and Rodriguez-Iturbe (2001), Laio, Porporato, Ridolfi and Rodriguez-Iturbe (2001), Porporato et al. (2001) and Rodriguez-Iturbe et al. (2001).

With this article, we want to illustrate the effects of environmental factors influencing the formation and distribution of various vegetation associations found within the study area. In particular, we hypothesise that the 'sudden' or marked change from microphyll Acaciadominated savannas to mesophyll savannas (Terminalia sericea, Combretum spp.) in the eastern communal areas is the result of a combination of increased rainfall and especially increased water availability in the deep, sandy soils of the Kalahari.

\section{Research method and design}

\section{Study area}

The Omaheke ['great sand desert'] forms the western fringe of the Kalahari basin (Mendelsohn \& el Obeid 2002, 2003; Mendelsohn et al. 2002) (Figure 1). The central, major part of the landscape is formed by an extensive sand plateau, sloping from the southern, western and north-western fringe towards the central east. The topography of the Kalahari sand plains is flat to almost flat. These Kalahari sands, with weak to little development in the profiles, are classified as haplic or ferralic Arenosols. ${ }^{1}$ These soils are generally deep to very deep and well drained. They have a low agricultural potential as they are leached, have a low water-holding capacity and a low nutrient status (Coetzee 2003; Mendelsohn et al. 2002; Strohbach et al. 2004).

Within this sandy plain, occasional dune fields occur (De Pauw et al. 1998; Thomas 1984). The sand dunes reach a height of up to $20 \mathrm{~m}$, forming an undulating to rolling landscape. The dune crest, dune slopes and foot of the dunes consist of ferralic Arenosols with haplic Arenosols mostly on the lower footslopes

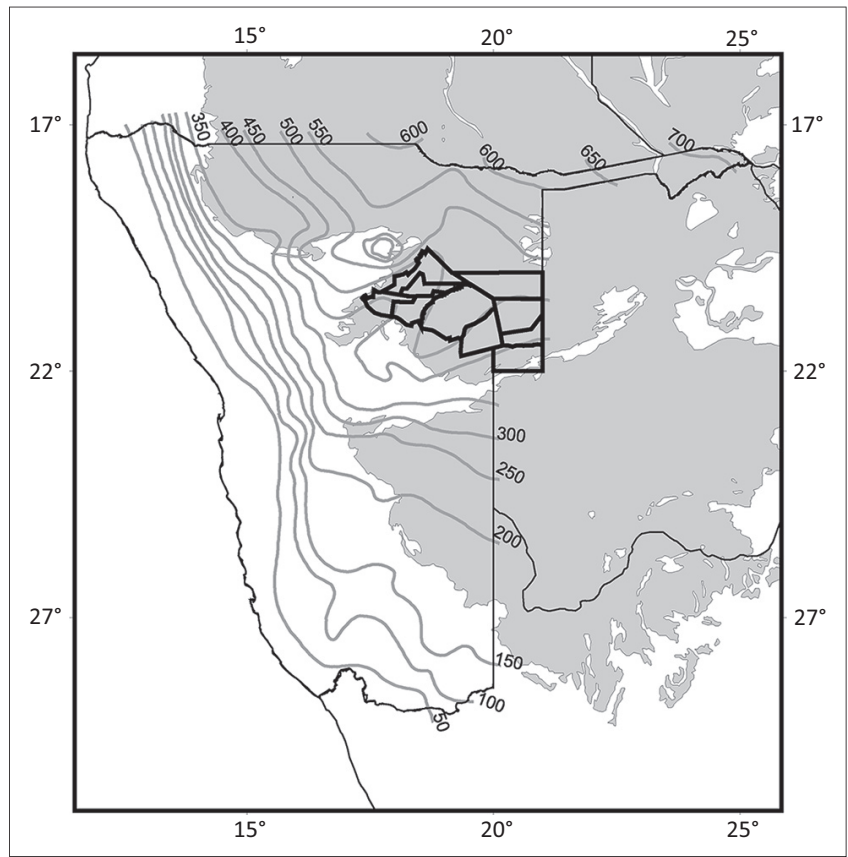

Source: Mendelsohn et al. (2002); Namibian Agricultural Resources Information System (2001). For more information, see the reference list for the article: Strohbach, B.J. \& Kutuahuripa, J.T., 2014, 'Vegetation of the eastern communal conservancies in Namibia: II. Environmental drivers', Koedoe 56(1), Art. \#1117, 12 pages. http://dx.doi.org/10.4102/ koedoe.v56i1.1117

The average annual rainfall isohyets (for Namibia) are indicated as grey lines, with their values noted along the side and the top of Namibia.

FIGURE 1: The study area (indicated in bold lines along the east-central border of Namibia) in relation to the Kalahari sand basin in southern Africa (grey shading).

1.Soil definitions follow the World Soils Reference Base (Food and Agricultural Organization \& UN Educational, Scientific and Cultural Organization 1988). A full description of the soil types found is presented in Online Appendix 1. 
of the dunes. Soils on the interdunal depressions and isolated small pans of the Kalahari vary in depth from moderately deep to very deep sandy soils. The two major soil types that occur within this soil-mapping unit are petric Calcisols (Table 1) and haplic Arenosols. Isolated pans have shallow haplic Calcisols with calcrete horizons surfacing and some gleying was occasionally found (Strohbach et al. 2004) (Figure 2).

The sand plateau is drained by a number of deeply incised drainage channels, commonly referred to as omiramba (singular: omuramba) (King 1963; Strohbach 2008). These fossil drainage lines were formed during the wetter phase predominating the early to mid-Pleistocene age. The depths and widths of the omiramba depend on the prevailing winds and water flows experienced throughout the ages. Very often, calcrete outcrops are exposed at the edges of the major omiramba, especially the Otjozondjou, Epukiro, Eiseb and Rietfontein omiramba. The major soil types of the omiramba are arenic or calcic Fluvisols, occasionally associated with petric or haplic Calcisols (Strohbach et al. 2004) (Table 1) (Figure 2).

Along the south-western fringes of the Kalahari sand basin, but also south and east of Gam, the sand cover is shallow, often overlaying calcretes, with occasional calcrete pans and reworked whitish, loose, unstructured Kalahari sands. The topography is flat to almost flat. Typical here are haplic Calcisols, whilst in the far north-east some eutric Cambisols (Table 1) have also been found (Strohbach et al. 2004) (Figure 2).

Floodplains occur between the Klein Omatako Omuramba and the Omuramba Omatako and stretch up to Okanguindi village, south-east of Okakarara. They are subjected to repeated seasonal flooding as a result of the relatively low relief. The continuous erosion of the surface horizon by water, results in the formation of many pans and watercourses throughout the area. Owing to continuous reshaping and removal of the parent material and topsoil, the soils of this mapping unit are much younger in terms of development and age. The dominant soils of this mapping unit, arenic Fluvisols (Table 1), are weakly developed and poorly structured (Figure 2). Soils within the lower positions are subjected to flooding and show signs of mottling caused by poor drainage and water-logging.

In the far north-west of the study area (north-west of Otjituuo towards Grootfontein), but also north of Gam, is a plateau with limestone related to the Karstveld. Hard and soft calcrete and/or limestone outcrops are exposed at the soil surface. The dominant soils are lithic and molic Leptosols, with some skeletic Leptosols being associated (Strohbach et al. 2004) (Figure 2).

The climate is relatively uniform, with a rainfall gradient ranging, on average, from just under $400 \mathrm{~mm}$ in the south to just under $500 \mathrm{~mm}$ in the north, annually (Figure 1). The variation in rainfall $(\mathrm{CV})$ is about $60 \%$ for the entire study area (Botha 1996; Mendelsohn et al. 2002; Namibian Agricultural Resources Information System [NARIS] 2001). This typical summer rainfall area has a dry winter and a dry and hot spring season (Figure 3). Frost is not unheard of in winter, with between 5 days of frost in the north and 30 days or more in the south (Mendelsohn et al. 2002; Southern African Science Service Centre for Climate Change and Adaptive Land Use [SASSCAL] WeatherNet 2012) (Figure 3a-3c). The average relative humidity drops to below $10 \%$ during the dry months, but rises to $70 \%-80 \%$ during the rainfall months (Mendelsohn et al. 2002).

Regular veld fires are known to occur within the study area (Le Roux 2011; Mendelsohn \& el Obeid 2002). The fire return period ranges between less than 2 years and 10 years and longer, with especially the north-eastern part of the study area being burned very frequently. As a combination of a variety of factors, including the fire return period, the seasonality of fires, et cetera, Le Roux (2011) determined a 'fire regime' for various areas in Namibia. Most of the study area is classed as having a 'mild' to 'moderate' fire regime.

\section{Procedure}

At the same time as the vegetation survey in April 2004, a survey of the major landscape types and associated soil types was conducted. In addition to describing the landscapes based on field observations and topographic map interpretation, soil profiles were exposed by digging soil pits on representative sites throughout the study area (Strohbach et al. 2004). However, because of the fairly labour-intensive sampling procedure, only 71 sample pits were dug. Very few of these were at the same localities as the vegetation sample plots (Strohbach 2014). This means that for this particular study, whilst also relying on existing geographic information system (GIS) sources (Le Roux 2011; Mendelsohn \& el Obeid 2002; Mendelsohn et al. 2002; NARIS 2001), only extrapolated environmental data were available. It thus made sense to use synoptic composition data of the associations and subassociations for all analyses, rather than the individual relevé data, for comparison to the available environmental data; see the summarised data used in Table 1. For all analyses, the Panicum gilvum-Marsilea vlei community was omitted as a potential outlier, also because only one relevé was collected in this community. Analytical soil data from the soil profile descriptions were augmented with standard soil parameters developed for the World Soil Reference Base (Batjes 2002).

\section{Available soil moisture}

Soil hydrological parameters, specifically saturated hydraulic conductivity, saturation matric potential and porosity, can be directly linked to the soil texture, that is, the percentage of sand, silt and clay in the soil (Cosby et al. 1984). We followed the convention of these authors and used the composition of the midpoint of the soil-textural class on the soil texture triangle. We used the soil characteristics of the dominant soil horizon in the case of soils with widely varying soil properties in their horizons; that is, we would ignore a shallow, sandy A-horizon and rather use the characteristics of the deeper, loamy B-horizon. Soil hydrological parameters were derived 


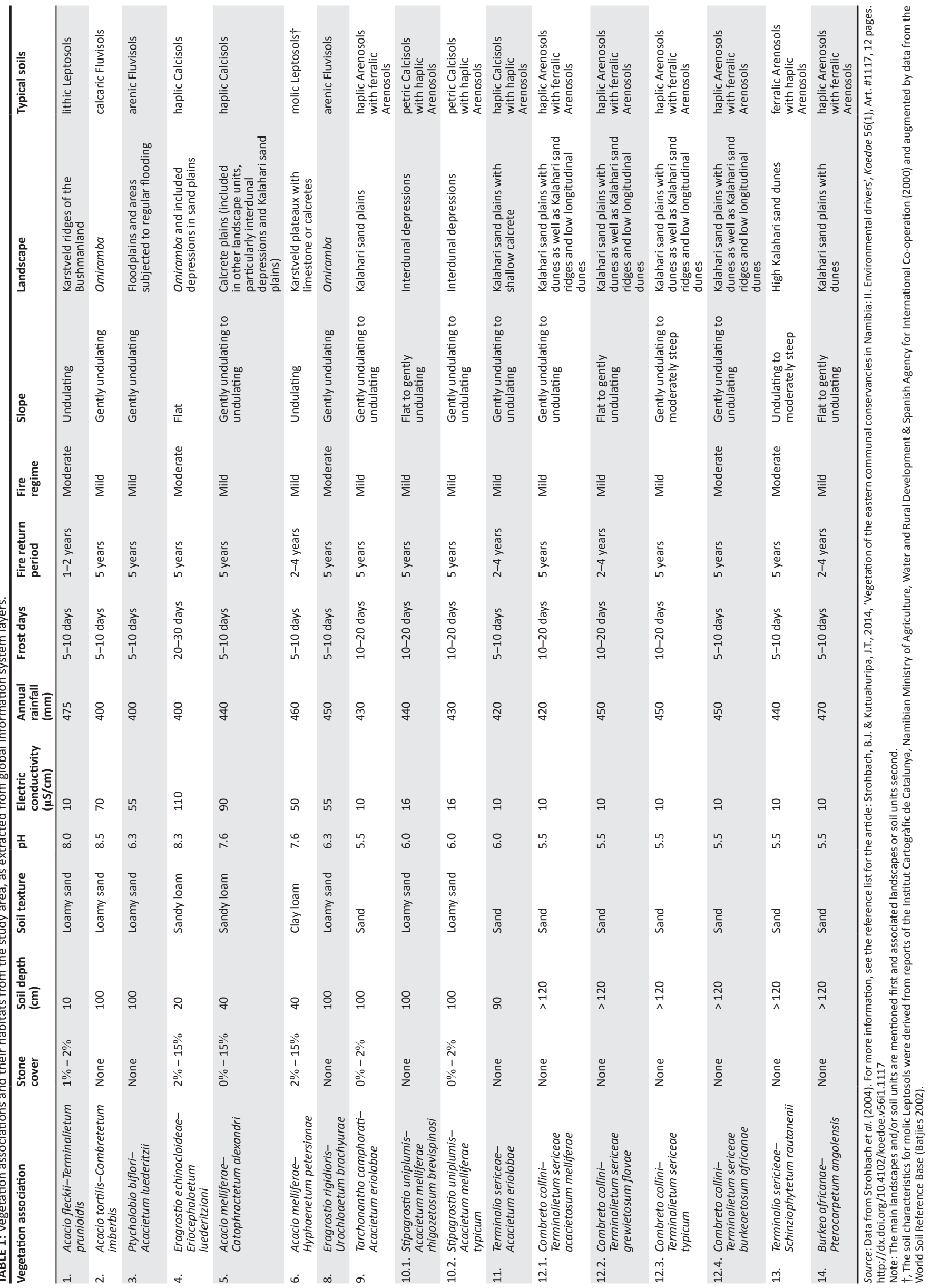


from the textural classes, using data provided by Cosby et al. (1984) and Laio, Porporato, Ridolfi and Rodriguez-Iturbe (2001). No attempt was made to estimate the actual soil matric potential based on annual rainfall, soil texture and soil depth, because, in many cases (especially within the various Arenosols), the depth of the soil profile is unknown, but it could reach depths of up to $250 \mathrm{~m}$ or deeper (Mendelsohn \& el Obeid 2002).

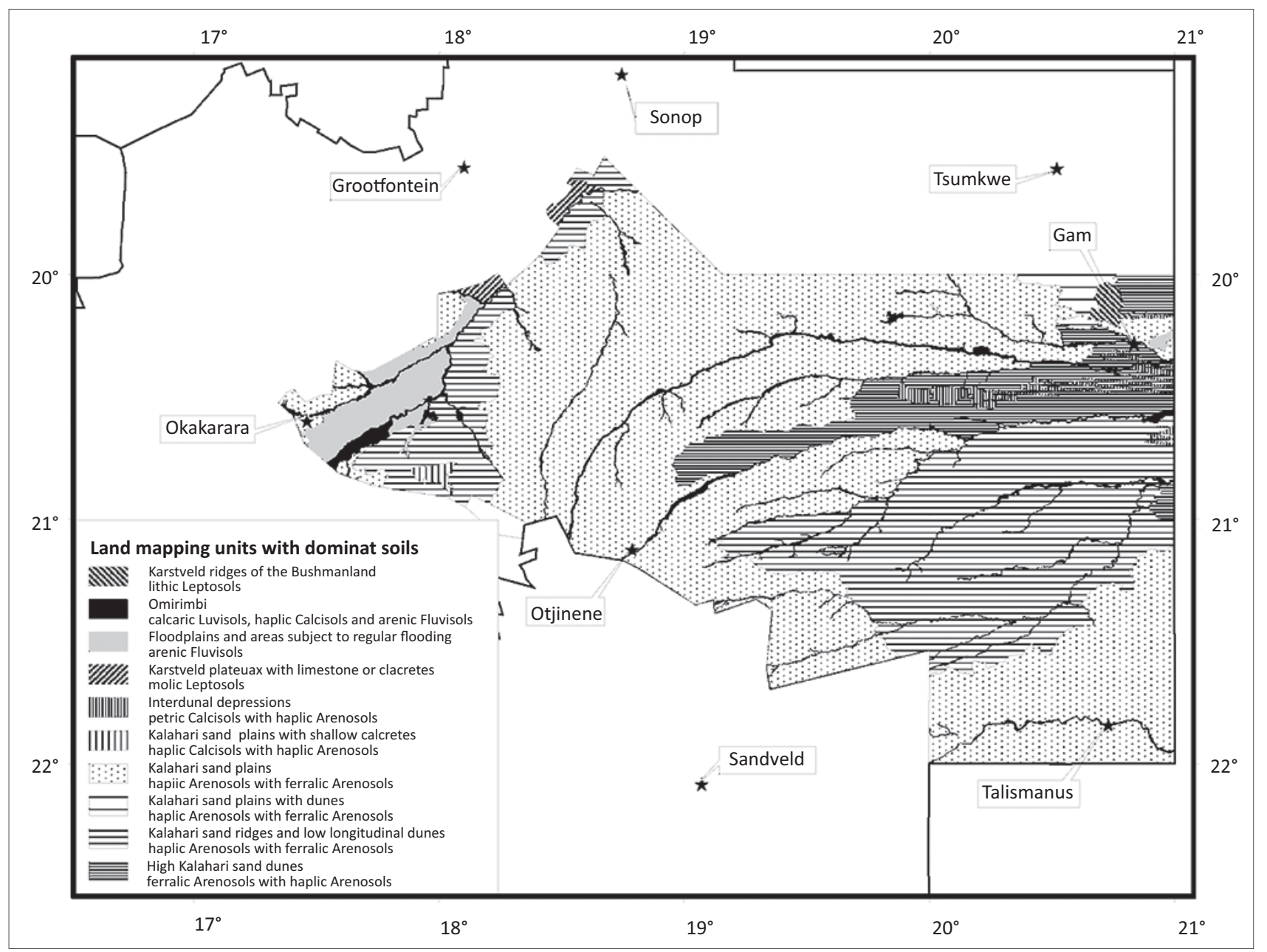

Source: Map adapted from Strohbach, B.J., Strohbach, M., Kutuahuripa, J.T. \& Mouton, H.D., 2004, 'A reconnaissance survey of the landscapes, soils and vegetation of the eastern communal areas (Otjiozondjupa and Omaheke Regions), Namibia', Unpublished report for the Desert Research Foundation of Namibia and the Desert Margins Programme, National Botanical Research Institute, Windhoek

FIGURE 2: Dominant landscape units within the study area, indicating also the dominant soils for these landscape units (compare with Table 1).

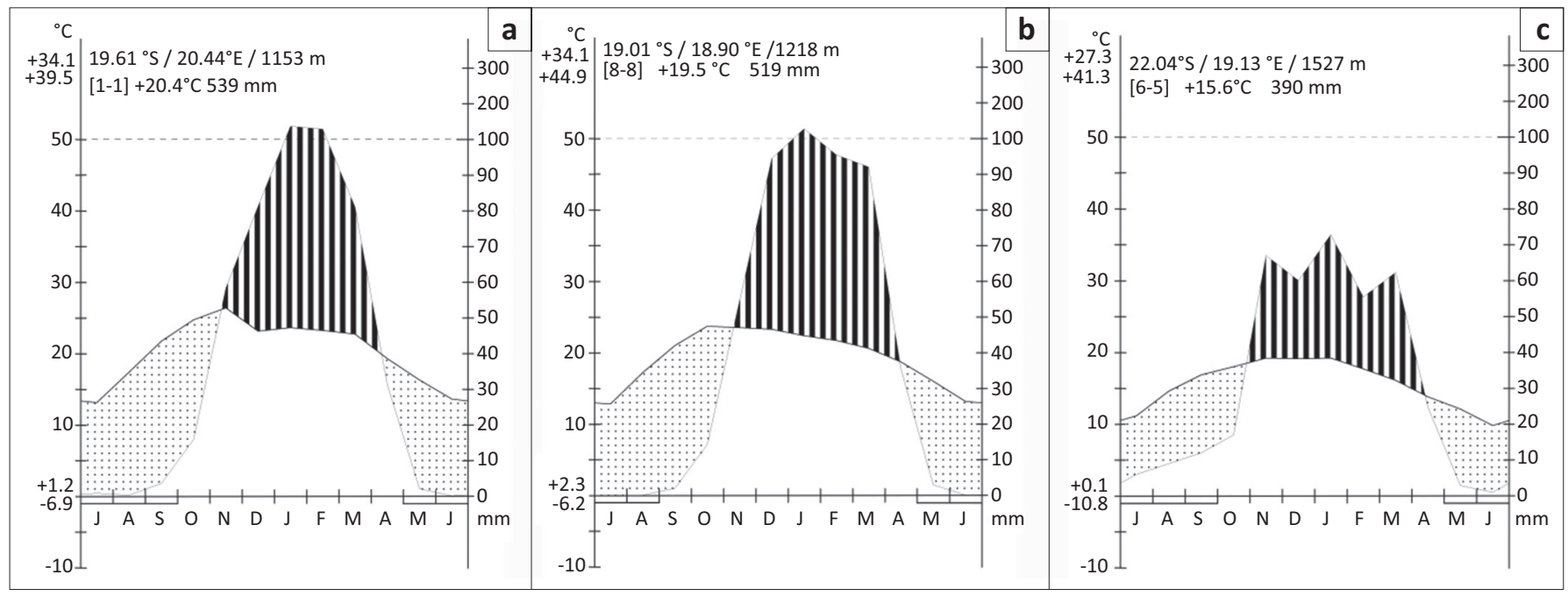

Source: SASSCAL WeatherNet (2012), diagrams following Walter, Harnickell and Mueller-Dombois (1975). For more information, see the reference list for the article: Strohbach, B.J. \& Kutuahuripa, J.T., 2014, 'Vegetation of the eastern communal conservancies in Namibia: II. Environmental drivers', Koedoe 56(1), Art. \#1117, 12 pages. http://dx.doi.org/10.4102/koedoe.v56i1.1117 FIGURE 3: Climate diagrams for the stations, (a) Tsumkwe and (b) Sonop (both to the north of the study area) and (c) Sandveld to the south of the study area. 


\section{Climatic data}

Data on mean annual rainfall and frost days were extracted by overlaying plot positions onto the relevant GIS layers. All other relevant climatic data (CV of rainfall, average minimum temperatures, relative humidity in both wet and dry seasons, etc.) were too uniform across the study area to warrant their consideration as significant environmental gradients (Botha 1996; Mendelsohn et al. 2002; NARIS 2001). The extracted data were averaged for the associations and these averages used in the analysis. In a similar way, the fire return period and fire regime (based on the data of Le Roux 2011) were extracted for plots and summarised for the associations.

\section{Environmental gradients}

In order to demonstrate the main environmental drivers, the vegetation data were processed in two ways: by means of a non-metric multidimensional scaling (NMS) ordination using PC-Ord 6 (McCune, Grace \& Urban 2002), as well as a classification of plant functional attributes using VegClass (Gillison 2002; Gillison \& Carpenter 1997).

Reciprocal averaging (Hill 1973) was not used because of a severe arch effect. As the data set was relatively small, the use of NMS, using the Sørensen distance measure, was regarded as more feasible. The ordination procedure was completed by using PC-Ord 5 (McCune et al. 2002) and repeated twice. The first run was based on a random starting configuration with 50 real data runs and 249 runs on randomised data. After 107 iterations a final solution was reached, with a stress of 7.196 and a final instability of 0.00001 . The results were saved and used as base configuration for the second run. This time, only 10 runs with real data were allowed, also requesting a Varimax rotation of the results. The environmental data were overlain as a biplot, to indicate the environmental gradients of interest. A second biplot was created, using plant functional attributes (see below) as variables.

As water availability is hypothesised to be the main driving force in the composition of the vegetation, plant functional attributes (PFAs) as related to water availability were utilised to illuminate these gradients. The PFAs were chosen according to criteria described by Gillison and Carpenter (1997), in order that they might be used in the VegClass software for analysis. In the context of this study, all pinnately compound leaves have been classified as 'filicoid' ('filicoid' leaves are, according to the description of Gillison \& Carpenter 1997, fern-like leaves). The PFAs were identified from a variety of sources, including the Tree Atlas of Namibia (Curtis \& Mannheimer 2005), the Field guide to trees and shrubs of Namibia (Mannheimer \& Curtis 2009), the Field guide to the plants of northern Botswana (Heath \& Heath 2009), Grasses of Namibia (Müller 2007), the Prodromus zur Flora von SWA (Merxmüller 1966) and a number of Internet sites such as JStor Plant Science (http://plants.jstor.org), Flora of Zimbabwe (http://www. zimbabweflora.co.zw/index.php) and Photo guide to plants of southern Africa (http://www.southernafricanplants.net/ index.php). The data were captured in VegClass, ensuring that individual species had the same functional attributes across syntaxa. This is contrary to the recommendations of Gillison and Carpenter (1997), but necessary as these PFAs were collected in retrospect; furthermore, this is acceptable as these PFAs represent the typical attributes of the species within the broad Forest Savanna and Woodland of the northern Kalahari (sensu Giess 1998). The distance between all associations, based on changing PFA combinations, was calculated using the Wald-Wolfowitz distance measure as recommended by Gillison and Carpenter (1997). As the software lacks an option to reduce the resulting distance matrix to two dimensions, the resulting distances were plotted using the distance measures from Association 14 (Burkeo africanae-Pterocarpetum angolensis) and Association 1 (Acacio fleckii-Terminalietum prunioidis) and as Axes 1 and 2 , respectively. Biplots of both the habitat and key PFA data were overlain onto this graph, again to elucidate the gradients. In all cases, the biplots were limited to those environmental variables or PFAs with an $r^{2}>0.3$.

As a total of 31 PFAs were identified (resulting in 123 combinations as plant functional types), it was decided to use only key PFAs in biplot overlays onto ordination diagrams. These key PFAs included the following: leaf size, leaf and photosynthetic adaptations, growth form (sensu Raunkiaer Mueller-Dombois \& Ellenberg 1974) and the number of perennial plants (opposing the growth form 'therophytes', which are annual plants). The leaf sizes have been combined as follows: microphyll leaves are all leaf sizes $\leq$ microphyll, sensu Gillison and Carpenter (1997), or $\leq 2025 \mathrm{~mm}^{2}$. Macrophyll leaves are all leaf sizes $\geq$ notophyll, sensu Gillison and Carpenter (1997), or $\geq 2025 \mathrm{~mm}^{2}$. These key PFA data are represented in Table 2, whilst the detailed PFA data are presented in Online Appendix 2.

Once the main environmental drivers were determined, the significance of these in affecting the compositional and plant functional changes between various vegetation associations was determined using a multiple linear regression analysis. For this, two runs of the procedure were completed, using the percentage occurrence of macrophyll and microphyll plants in each association as dependent variables and the mean annual rainfall, mean number of frost days, mean soil depth as well as soil texture, expressed as mean percentage sand, silt and clay, as independent variables. Soil $\mathrm{pH}$ and electric conductivity was not used in this calculation, as these factors were assumed to be closely related to the soil texture. The F-value for variables to be entered in the regression was set to 0.5 for forward selection. For the calculation, the software STATISTICA (2013) was used.

\section{Results}

The NMS ordination results and the VegClass results are depicted in Figure 3 and Figure 4, respectively. The NMS results represent $91.5 \%$ of the variation between the various 
TABLE 2: Simplified key plant functional attributes, expressed as a percentage of all species found in the relevant associations.

\begin{tabular}{|c|c|c|c|c|c|c|c|c|c|c|c|c|c|}
\hline \multirow[t]{2}{*}{ Association } & \multicolumn{2}{|c|}{ Leaf size } & \multicolumn{5}{|c|}{ Leaf adaptations } & \multicolumn{5}{|c|}{ Growth form } & \multirow{2}{*}{$\begin{array}{c}\text { Duration } \\
\begin{array}{c}\text { Perennial } \\
\text { plants }\end{array}\end{array}$} \\
\hline & $\begin{array}{l}\text { Micro- } \\
\text { phyll }\end{array}$ & $\begin{array}{l}\text { Macro- } \\
\text { phyll }\end{array}$ & $\begin{array}{l}\text { Filicoid } \\
\text { leaves }\end{array}$ & $\begin{array}{l}\text { Sclero-phyll } \\
\text { leaves }\end{array}$ & $\begin{array}{l}\text { Succulent } \\
\text { leaves }\end{array}$ & $\begin{array}{l}\text { Deciduous } \\
\text { plants }\end{array}$ & $\begin{array}{c}\text { Cortic } \\
\text { chlorophyll }\end{array}$ & $\begin{array}{l}\text { Phanero- } \\
\text { phyte }\end{array}$ & $\begin{array}{l}\text { Chama- } \\
\text { phyte }\end{array}$ & $\begin{array}{c}\text { Hemi- } \\
\text { cryptophyte }\end{array}$ & $\begin{array}{l}\text { Crypto- } \\
\text { phyte }\end{array}$ & $\begin{array}{l}\text { Thero- } \\
\text { phyte }\end{array}$ & \\
\hline A1 & 75.27 & 22.58 & 9.68 & 8.60 & 3.23 & 37.63 & 4.30 & 25.81 & 22.58 & 9.68 & 3.23 & 38.71 & 61.29 \\
\hline A3 & 88.89 & 10.19 & 10.19 & 6.48 & 4.63 & 15.74 & 1.85 & 11.11 & 12.96 & 7.41 & 2.78 & 65.74 & 34.26 \\
\hline A4 & 88.79 & 9.48 & 11.21 & 13.79 & 4.31 & 16.38 & 0.00 & 11.21 & 20.69 & 15.52 & 6.90 & 45.69 & 54.31 \\
\hline A5 & 80.20 & 18.81 & 11.39 & 7.92 & 5.45 & 27.23 & 1.49 & 11.88 & 19.80 & 9.90 & 10.89 & 47.52 & 52.48 \\
\hline A6 & 84.03 & 14.58 & 11.81 & 8.33 & 4.17 & 20.14 & 2.08 & 16.67 & 10.42 & 10.42 & 7.64 & 54.86 & 45.14 \\
\hline A8 & 83.61 & 15.30 & 13.66 & 8.20 & 2.73 & 24.04 & 1.64 & 10.38 & 12.57 & 12.02 & 14.21 & 50.82 & 49.18 \\
\hline A9 & 82.68 & 16.20 & 11.17 & 7.82 & 3.35 & 27.93 & 1.68 & 12.85 & 19.55 & 11.73 & 12.29 & 43.58 & 56.42 \\
\hline A10.1 & 81.55 & 16.99 & 10.68 & 8.25 & 4.85 & 27.18 & 1.46 & 11.17 & 16.99 & 9.22 & 12.14 & 50.49 & 49.51 \\
\hline A10.2 & 80.09 & 18.52 & 11.57 & 9.26 & 5.09 & 26.85 & 1.39 & 14.35 & 20.83 & 6.48 & 12.04 & 46.30 & 53.70 \\
\hline A11 & 81.50 & 17.34 & 11.56 & 7.51 & 4.62 & 26.01 & 1.16 & 13.29 & 16.76 & 10.40 & 10.40 & 49.13 & 50.87 \\
\hline A12.1 & 78.13 & 20.09 & 12.05 & 8.37 & 4.91 & 26.34 & 0.89 & 11.16 & 18.75 & 10.27 & 13.84 & 45.98 & 54.02 \\
\hline A12.3 & 77.54 & 20.32 & 13.37 & 9.04 & 4.28 & 27.27 & 1.60 & 12.30 & 17.11 & 10.70 & 14.97 & 44.92 & 55.08 \\
\hline A12.4 & 73.47 & 23.81 & 16.33 & 7.48 & 2.04 & 28.57 & 2.04 & 16.33 & 16.33 & 11.56 & 14.97 & 40.82 & 59.18 \\
\hline A13 & 71.58 & 28.42 & 17.89 & 5.26 & 1.05 & 29.47 & 2.11 & 29.47 & 10.53 & 11.58 & 6.32 & 42.11 & 57.89 \\
\hline A14 & 67.33 & 30.69 & 15.84 & 7.92 & 1.98 & 35.64 & 3.96 & 25.74 & 11.88 & 13.86 & 13.86 & 34.65 & 65.35 \\
\hline
\end{tabular}

Source: Leaf size data sensu Gillison, A.N. \& Carpenter, G., 1997, 'A generic plant functional attribute set and grammar for dynamic vegetation description and analysis', Functional Ecology 11, 775-783

Leaf sizes have been combined as follows: Microphyll leaves are all leaf sizes $\leq$ microphyll sensu Gillison and Carpenter (1997), or $\leq 2025$ mm². Macrophyll leaves are all leaf sizes $\geq$ notophyll sensu Gillison and Carpenter (1997), or $>2025 \mathrm{~mm}^{2}$.

associations, with Axis 1 representing 52.8\% and Axis 2 representing $38.7 \%$.

Rainfall, soil depth and sandy soils are positively correlated with ordination Axis 1, whilst the clay and silt content, combined with increasing $\mathrm{pH}$, are negatively correlated with this axis (Figure 4a). As expected, hydraulic conductivity is co-correlated with sandy soils along the main axis, whilst soil porosity, soil matric potential and soil pore volume are closely associated with the finer textured soils.

These tendencies are partially confirmed by the VegClass results, with the soil texture also influencing the distribution of associations in relation to Association 14 (Burkeo africanaePterocarpetum angolensis) (Figure 5a). However, the soil hydraulic parameters do not seem to be of importance in the VegClass scatter plot.

The main gradient manifests itself in a gradual change from mesophyll to microphyll plants - the mesophyll plants, as expected, being associated with the deep, sandy soils under higher rainfall regimes, whilst the microphyll plants are more restricted to the loamy soils (Figure $4 \mathrm{~b}$ ). Together with the microphylls, the loamy soils support a strong annual flora (therophytes) and plants with succulent leaves, whereas the sandy soils support macrophyll plants, perennials, especially phanerophytes, but also plants with filicoid leaves and deciduous plants.

Exactly the same combinations of PFAs are found to correlate with the main gradient in the VegClass scatter diagram (Figure 5b). The two results differ in the reaction to the second axis - within the NMS ordination, cryptophytes (e.g. geophytes, geoxylic suffrutices sensu White 1976) are negatively correlated to Axis 2, whilst chamaphytes (dwarf shrubs) react to the secondary axis of the VegClass results. No indication of a sensitivity to frost could be identified, whilst sclerophyll leaves are only very weakly correlated with the secondary axis of the NMS $\left(r^{2}<0.2\right)$.

Fire regime did feature in the VegClass scatter plot. The fire regime in the study area generally varies between mild to moderate (Le Roux 2011) and does not show any tendency on the ordination diagram (Figure 4a). It is more likely that with certain associations (especially the widespread Combreto collini-Terminalietum sericeae on the Kalahari sand plains), fire is primarily responsible for the structure and finer compositional changes (Figure 6). This, however, needs to be studied in greater depth.

The results of the multiple linear regressions indicate that, for both microphyll and macrophyll plants, rainfall is a significant driver in the occurrence of the plants. Soil depth and soil texture (sand and clay content) were only insignificantly associated with this change in composition, whilst other factors did not obtain the necessary $F$-value to be taken up in the regression (Table 3).

\section{Discussion}

\section{Climatic gradients versus changes in soil types}

Rainfall has, by far, the strongest and most consistent effect on the vegetation in arid to semi-arid climates. This also holds true for the vegetation within the present study area, which was proven to be the only significant driver in the change from microphyll to macrophyll vegetation (Table 3 ). Our present gradient is roughly $200 \mathrm{~km}$ long, with a rainfall gradient of less than $150 \mathrm{~mm}$. Skarpe (1996) described a similar change in vegetation as it occurs across Botswana along a rainfall gradient over $1100 \mathrm{~km}$ on uniformly sandy 


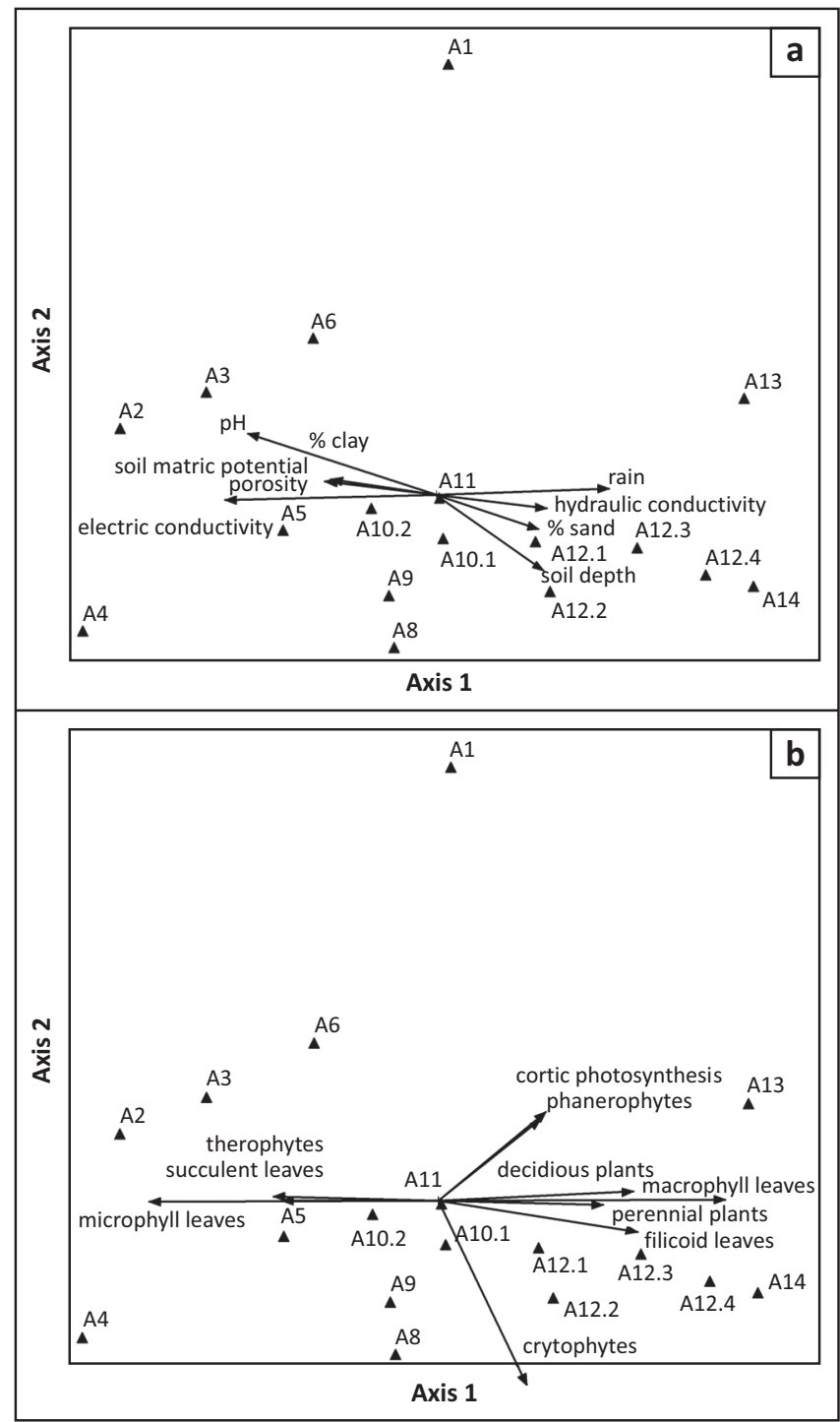

FIGURE 4: Non-metric multidimensional scaling results of the synoptic vegetation data, depicting, (a) biplot overlaid with the habitat factors and (b) biplot overlaid with the key plant functional attributes.

soils; she unfortunately does not provide rainfall differences in her paper. From the geographical description, it is assumed to be a gradient from Bokspits in far south-west Botswana (177 mm mean annual precipitation - Bhattachan et al. 2012) to the four-country corner with Zimbabwe, Namibia and Zambia in north-east Botswana. For nearby Katima Mulilo in north-east Namibia, a long-term mean annual precipitation of $758 \mathrm{~mm}$ has been recorded (Namibia Meteorological Services 1997). From this, a rainfall gradient of approximately $580 \mathrm{~mm}$ is assumed for Skarpe's study. Her main finding is that broad-leafed trees and grasses are positively correlated with increasing precipitation, whilst fine-leafed phanerophytic species and chamaphytic species were positively correlated with increasing aridity along the gradient.

Whereas Skarpe (1996) describes a gradual change in vegetation over a rather lengthy gradient, the change from microphyll-dominant vegetation (associations A1 A11) to macrophyll-dominant vegetation (associations
A12 - A14) within the study area is rather abrupt over a very short geographical distance (cf. Hüttich et al. 2009; Strohbach 2014). These dramatic changes occur over virtually no rainfall gradient at all and are related to the change in soil type, from a fine-textured, loamy soil to the coarse-textured, deep sands of the Kalahari basin, as suggested by Leser (1972). Tinley (1982) describes similar dramatic changes resulting from changes in soil texture for Mozambique. These changes are caused by the difference in water availability as a result of differences in soil moisture relationships (in particular, a higher soil matric potential and higher porosity, but also higher adhesion, in loamy soils versus a high hydraulic conductivity in sandy soils), causing the inverse texture effect (Figure 4) (Austin et al. 2004; Noy-Meir 1973; Porporato et al. 2001). The gradual change between the various subassociations of the Combreto collini-Terminalietum sericeae (A12) and the Burekeo africanaePterocarpetum angolensis (A14) from south to north happens on similar sandy soils and can be compared to the changes in PFAs across a climatic gradient described by Skarpe (1996).

\section{Plant adaptations to environmental drivers}

Owing to the higher hydraulic conductivity of sandy soils, rainfall infiltrates faster, but, at the same time, water percolates to deep soil layers. This means that water is available in the upper soil layers for a comparatively short period during the rainy season, whereas deeper soil layers (below $2 \mathrm{~m}$ ) act as a reservoir for deeper-rooted plants (B. Strohbach, unpublished data). Therefore, deep-rootedness is a prerequisite for the survival of phanerophytes growing on such sandy soils. This holds true for most of these species (Hipondoka \& Versfeld 2006; Hipondopka et al. 2003; Mwita et al. 2008; Savory 1963; see also Timberlake \& Calvert 1993). Deep-rooted geoxylic suffrutices, for example Entada arenaria and Dichapetalum cymosum, better known from moister savannas and woodlands of the Sudano-Zambezian Ecoregions (500 mm - $700 \mathrm{~mm}$ mean annual rainfall) (White 1976), thus also succeed in growing in this environment. The latter species (gifblaar or magou) is problematic throughout the study area, where it can increase rapidly in density by taking advantage of disturbances caused by high numbers of cattle (Bester 1989).

Another adaptation to the temporary high availability of water in sandy soils during the rainy season (because of high infiltration rate) can be seen in stem succulents, specifically various Commiphora species (Figure $4 \mathrm{~b}$ ). These are able to photosynthesise, also during the dry season, by means of a photosynthetic layer under the translucent bark an adaptation to xeric environments (referred to as 'cortic photosynthesis' by Gillison \& Carpenter 1997). Whether pinnately compound leaves ('filicoid leaves') point to any specific adaptation, or are rather a coincidence related to the species composition, could not be established.

The grass sward of the sandy soils is dominated by the annual species Aristida stipitata and Megaloprotachne albescens. Most grass roots tend to be limited to the upper $40 \mathrm{~cm}$ to $60 \mathrm{~cm}$ 


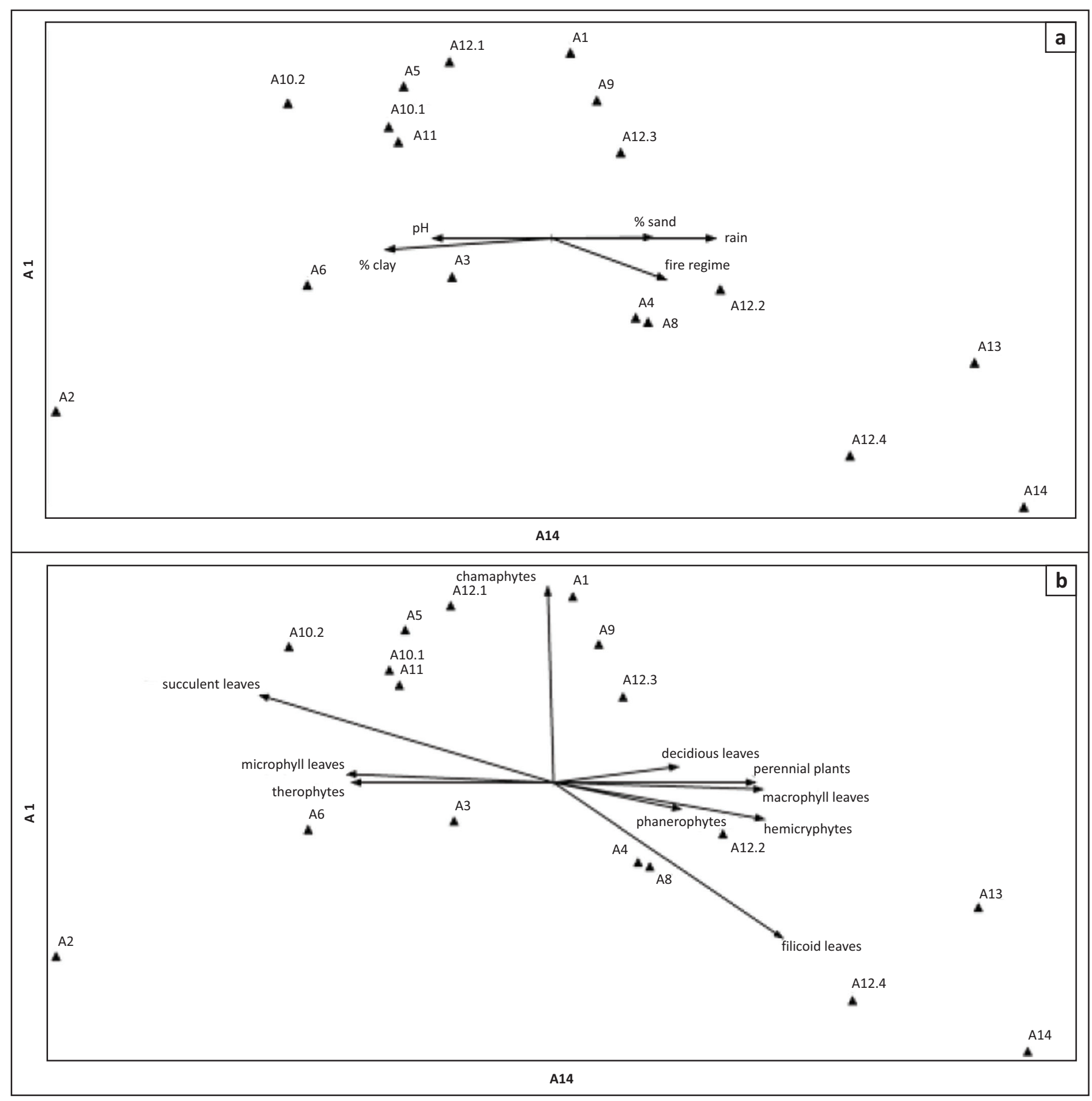

FIGURE 5: Scatter diagrams of the distances between various vegetation associations based on their plant functional attributes (using the distances from associations 14 and 1 on the $x$-axis and $y$-axis respectively), depicting, (a) biplot overlaid by the habitat data and (b) biplot overlaid with the key plant functional attributes.

of the soil profile; they are therefore unable to access water from deeper water resources (Hipondoka et al. 2003). With this annual character, the grass sward utilises a strategy of growing rapidly during the rainy season to exploit available resources to the fullest in the shortest possible time, but does not store water in underground organs or access the water that is available in deeper soil layers during adverse seasons. The few perennial grass tufts either have hairy leaves (e.g. Digitaria seriata), or are extremely fine-leaved (e.g. Stipagrostis uniplumis var. uniplumis) as an adaptation to this harsh environment. Digitaria seriata is also often found within bush clumps, making use of both shade and increased water infiltration as a result of stem flow under these canopies.
Similar patterns were found in other arid environments (Martinez-Meza \& Whitford 1996; Pressland 1973). Perennial grasses within the Kalahari are also known to utilise inverse hydraulic lift to channel water down into the soil profile (to a depth of between $50 \mathrm{~cm}$ and $100 \mathrm{~cm}$ ). This is postulated as a potential mechanism (not only by grasses, but also by trees) to create an own 'reservoir' of soil water for use during the dry season (Schulze et al. 1998).

Most of the phanerophytes growing on sandy soils are deciduous, shedding their leaves during the dry winter and hot, dry spring months (Table 2, own observations). This is a typical adaptation to avoid water loss (Fensham \& 

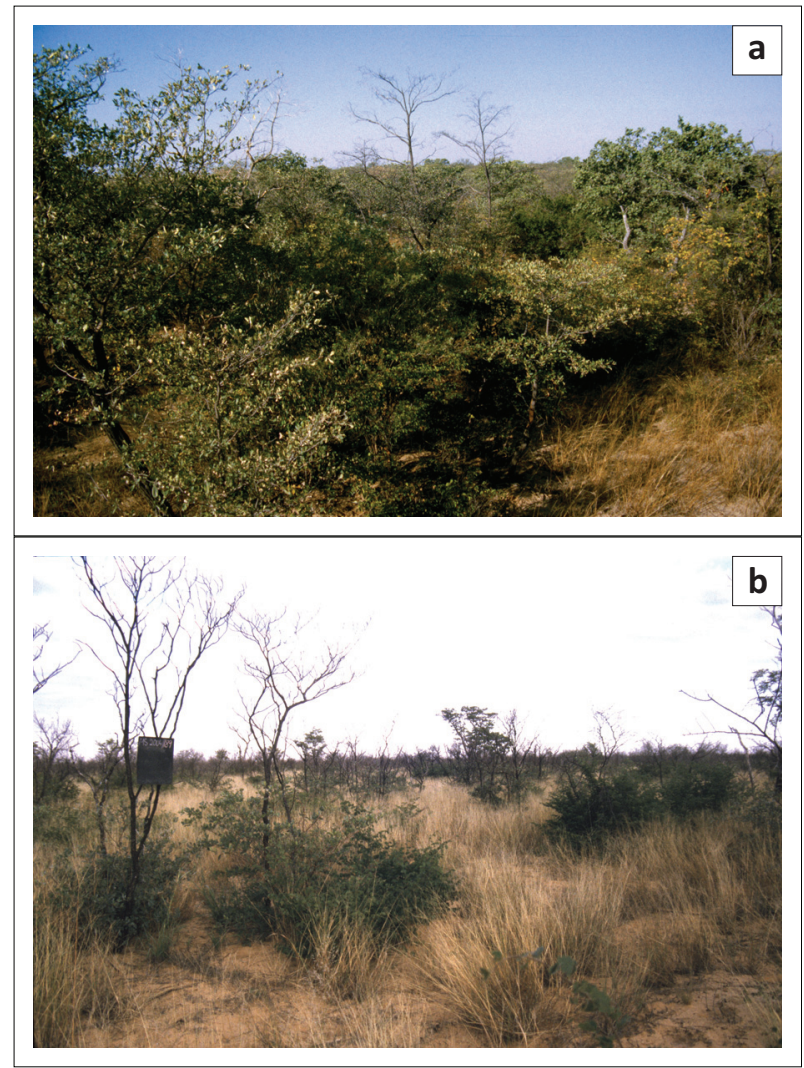

Source: Photographed by Marianne Strohbach in 2004

FIGURE 6: Fires have a severe structure-altering effect on bushlands and shrublands of especially the Combreto collini-Terminalietum sericeae typicum (subassociation 12.3), as seen from, (a) unburned bushland and (b) vegetation reduced to a low shrubland after a severe fire.

TABLE 3: Multiple linear regression results for the dependent variables 'macrophyll plants' and 'microphyll plants', respectively.

\begin{tabular}{|c|c|c|c|c|}
\hline \multirow[t]{2}{*}{ Category } & \multicolumn{2}{|c|}{$\begin{array}{c}\text { Macrophyll plants }\left(F_{4,12}=8.981,\right. \\
\left.\quad p<0.01, R^{2}=0.750\right)\end{array}$} & \multicolumn{2}{|c|}{$\begin{array}{c}\text { Microphyll plants }\left(F_{4,12}=9.684\right. \\
\left.\quad p<0.01, R^{2}=0.764\right)\end{array}$} \\
\hline & Coefficient & Significance & Coefficient & Significance \\
\hline Rain & 0.678 & $p<0.010$ & -0.715 & $p<0.010$ \\
\hline Soil depth & 0.476 & $p=0.112$ & -0.414 & $p=0.150$ \\
\hline$\%$ Clay & 0.799 & $p=0.231$ & -0.628 & $p=0.328$ \\
\hline$\%$ Sand & 0.800 & $p=0.298$ & -0.609 & $p=0.411$ \\
\hline Intercept & -77.288 & - & 141.343 & - \\
\hline
\end{tabular}

Fairfax 2009; Seghieri, Floret \& Pontanier 1995). Many phanerophytes, especially Terminalia sericea and various Combretum spp., have hairy leaves, an adaptation typically associated with psammophil plants (Warming 1909).

Within this study, deciduous plants were not limited to the sandy soils. Many species growing on loamy soils exhibit the same adaptation; however, several species are distinctly evergreen (e.g. Boscia albitrunca) or at least semi-deciduous, that is, shedding their leaves just before the next leaf flush (e.g. Acacia erioloba, Acacia hebeclada subsp. hebeclada). These evergreen to semi-deciduous species are also deep-rooted (Canadell et al. 1996; Moustakas et al. 2006; Schulze et al. 1998), enabling them to obtain water from deep soil layers during the dry season. Overall, however, the tendency is for the leaves to become distinctly smaller on the more loamy soils, an indication that the soil moisture availability is far lower on loamy soils than on sandy soils.
An extreme case of edaphic aridity is presented by the shallow calcrete pans of the Eragrostio echinochloideae-Eriocephaloetum luederitziani (A4). In addition to the very shallow profile, the soil is characterised by a high skeletal content, a high $\mathrm{pH}(>8)$ and a relatively high electric conductivity $(>100 \mu \mathrm{S} / \mathrm{cm})$. Moreover, the low soil volume can only store limited quantities of water, resulting in this water being saturated with ions, which means that it is not readily available to plants. The nature of these soils is manifested in the vegetation structure; the association being dominated by dwarf shrubs and, furthermore, within this association, $14 \%$ of all species had sclerophyll leaves (compared to an average of $6 \%-9 \%$ for all other associations) and a relatively high microphyll leaf component (89\%) (Table 2).

Although fire is known to have a severe influence on the vegetation composition in the Kavango and Zambezi regions (Geldenhuys 1977; Le Roux 2011; Mendelsohn \& el Obeid 2003; Mendelsohn \& Roberts 1997; Strohbach \& Petersen 2007), only structural alterations were evident during the present study (Figure 6). It is thus unlikely that fire is a driving factor in the discrimination of vegetation associations within the study area.

\section{Shortcomings in data analysis}

A major shortcoming of this study is the fact that only synoptical data (both for vegetation composition as well as for environmental variables) could be employed. Because of this, the clear soil gradients illustrated by the ordination techniques were not conclusive in the multiple linear regression. Future studies concerning such moisture relations should take this problem into consideration.

\section{Conclusion}

The study supports the hypothesis that the broad-leafed savanna of the Kalahari is limited in distribution by the deep sands, as a result of better soil moisture conditions. The improved soil moisture conditions in the Kalahari sands are a result of the inverse texture effect (Noy-Meir 1973). In combination with increased rainfall to the north, this even allows tall trees to grow and replace the dominating shrublands with woodlands, as is evident from the transition between the Combreto collini-Terminalietum sericeae (A12) and the Burkeo africanae-Pterocarpetum angolensis (A14) - roughly coinciding with the $500 \mathrm{~mm}$ rainfall isohyet.

Deep-rootedness of phanerophytic species is one of the major adaptations of psammophil plants to utilise available water resources, but also to recharge and redistribute soil moisture resources in the profile (Burgess et al. 1998; Kizito et al. 2012; Martinez-Meza \& Whitford 1996; Schulze et al. 1998). A better understanding of these mechanisms is essential if one wishes to gain a clear grasp of savanna dynamics.

Furthermore, predictions regarding the effects of global climate change on the vegetation in the Kalahari environment can be improved by understanding the strategies employed by different plant species in the utilisation of water. It is 
predicted that, over the next 50 years, rainfall will decrease over Namibia, resulting in less available grazing for extensive livestock production (Midgley et al. 2005). In another study, it is predicted that the sands of the Kalahari basin will be remobilised during the next 50 years, resulting in largely unvegetated mobile dunes, as a result of global climate change (Thomas, Knight \& Wiggs 2005). We postulate that climate change will manifest itself initially through a change in composition, from the present mesophyll savanna to a microphyll (Acacia-dominated) savanna, very similar to that of the present Camelthorn savanna sensu Giess (1998). The Camelthorn savanna forms part of the greater Kalahari landscape on sandy soils, between about $250 \mathrm{~mm}$ and $400 \mathrm{~mm}$ mean annual rainfall, to the south of the present study area. It is, however, doubtful whether the grass sward will, under conditions of prolonged drought, develop to the present, relatively productive state. An added danger to productive savannas is the ongoing practice of harvesting Terminalia sericea for fencing poles. Already planned are projects to harvest 'invader' bush within the study area, to be used as fuel for power generation. Such large-scale removal of shrubs and small trees from the already poor landscape will inevitably lead to reduced water infiltration into the soil (because of reduced stem flow) and reduced water redistribution within the soil profile, in turn leading to less favourable conditions for grasses. The net effect will be an accelerated desertification through a 'man-made drought'.

\section{Acknowledgements}

Thanks are due to Ms Marianne Strohbach for assistance with the vegetation survey, as well as to Mr Heiner Mouton for helping with the soil survey. The soil samples were analysed by the Agriculture Laboratory, Directorate of Agricultural Research and Training, in Windhoek. This project was co-funded by the Global Environment Facility through the Desert Margins Programme and the Government of Namibia, through the recurrent budget of the Directorate of Agricultural Research and Training.

\section{Competing interests}

The authors declare that they have no financial or personal relationships which may have inappropriately influenced them in writing this article.

\section{Authors' contributions}

B.J.S. (Polytechnic of Namibia) was the project leader. He was involved in the vegetation survey and was responsible for analysing the data and writing up the article. J.T.K. (Ministry of Agriculture, Water and Forestry) was responsible for the soil survey and description of the soil types. Both contributed to the interpretation of the results.

\section{References}

Austin, A.T., Yahdjian, L., Stark, J.M., Belnap, J., Porporato, A., Norton, U. et al., 2004 'Water pulses and biogeochemical cycles in arid and semiarid ecosystems', Oecologia 141, 221-235. http://dx.doi.org/10.1007/s00442-004-1519-1
Batjes, N.H., 2002, 'Soil parameter estimates for the soil types of the world for use in global and regional modelling' (version 2.1), ISRIC report 2002/02c, International Food Policy Research Insititute and International Soil Reference and Information Centre, Wageningen.

Bester, F.V., 1989, 'Navorsing gedoen met betrekking tot gifblaar Dichapetalum cymosum [Research done concerning poison leaf Dichapetalum cymosum]', Agricola 7, 60-64.

Bhattachan, A., Tatlhego, M., Dintwe, K., O'Donnell, F., Caylor, K.K., Okin, G.S. et al., 2012, 'Evaluating ecohydrological theories of woody root distribution in the Kalahari', PLOS ONE 7, e33996. http://dx.doi.org/10.1371/journal. pone.0033996

Botha, L., 1996, Rainfall as an indicator of the agroclimate of Namibia, MDipTech thesis, Department of Meteorology, Technikon Pretoria.

Brady, N.C. \& Weil, R.R., 2002, The nature and properties of soils, 13th edn., Prentice Hall, Upper Saddle River.

Burgess, S.S.O., Adams, M.A., Turner, N.C. \& Ong, C.K., 1998, 'The redistribution of soil water by tree root systems', Oecologia 115, 306-311. http://dx.doi.org/10.1007/ s004420050521

Canadell, J., Jackson, R.B., Ehleringer, J.B., Mooney, H.A., Sala, O.E. \& Schulze, E.-D., 1996, 'Maximum rooting depth of vegetation types at the global scale', Oecologia 108, 583-595. http://dx.doi.org/10.1007/BF00329030

Coetzee, M.E., 2003, 'Characteristics of Namibian soils in a nutshell', Spotlight on Agriculture 65 .

Cosby, B.J., Hornberger, G.M., Clapp, R.B. \& Ginn, T.R., 1984, 'A statistical exploration of the relationships of soil moisture characteristics to the physical properties of soils', Water Resources Research 20, 682-690. http://dx.doi.org/10.1029/ WR020i006p00682

Curtis, B. \& Mannheimer, C., 2005, Tree Atlas of Namibia, National Botanical Research Institute, Windhoek

De Pauw, E., Coetzee, M.E., Calitz, A.J., Beukes, H. \& Vits, C., 1998, 'Production of an agro-ecological zones map of Namibia (first approximation). Part II: Results', Agricola 10, 33-43.

Food and Agricultural Organization \& UN Educational, Scientific and Cultural Organization, 1988, 'Soil map of the world - Revised legend', World Soil Resources Report 60, FAO, Rome.

Fensham, R.J. \& Fairfax, R.J., 2009, 'Drought-related tree death of savanna eucalypts: Species susceptibility, soil conditions and root architecture', Journal of Vegetation Science 18, 71-80. http://dx.doi.org/10.1111/j.1654-1103.2007.tb02517.x

Geldenhuys, C.J., 1977, 'The effect of different regimes of annual burning on two woodland communities in Kavango', South African Forestry Journal 103, 32-42. http://dx.doi.org/10.1080/00382167.1977.9629467

Giess, W., 1998, 'A preliminary vegetation map of Namibia', Dinteria 4, 1-112.

Gillison, A., 2002, 'A generic, computer-assisted method for rapid vegetation classification and survey: Tropical and temperate case studies', Conservation Ecology 6, 3.

Gillison, A.N. \& Carpenter, G., 1997, 'A generic plant functional attribute set and grammar for dynamic vegetation description and analysis', Functional Ecology 11 775-783. http://dx.doi.org/10.1046/j.1365-2435.1997.00157.x

Heath, A. \& Heath, R., 2009, Field guide to the plants of northern Botswana including the Okavango Delta, Kew Publishing, Royal Botanic Gardens, Kew.

Hill, M.O., 1973, 'Reciprocal averaging: An eigenvector method of ordination', Journal of Ecology 61, 237-249. http://dx.doi.org/10.2307/2258931

Hipondoka, M.H.T. \& Versfeld, W.D., 2006, 'Root system of Terminalia sericea shrubs across rainfall gradient in a semi-arid environment of Etosha National Park, Namibia', Ecological Indicators 6, 516-524. http://dx.doi.org/10.1016/j ecolind.2005.07.004

Hipondoka, M.H.T., Aranibar, J.N., Chirara, C., Lihavha, M. \& Macko, S.A., 2003, 'Vertical distribution of grass and tree roots in arid ecosystems of Southern Africa: Niche differentiation or competition?', Journal of Arid Environments 54, 319-325. http://dx.doi.org/10.1006/jare.2002.1093

Hüttich, C., Gessner, U., Herold, M., Strohbach, B.J., Schmidt, M., Keil, M. et al., 2009, 'On the suitability of MODIS time series metrics to map vegetation types in dry savanna ecosystems: A case study in the Kalahari of NE Namibia', Remote Sensing 1, 620-643. http://dx.doi.org/10.3390/rs1040620

Institut Cartogràfic de Catalunya, Namibian Ministry of Agriculture, Water and Rural Development \& Spanish Agency for International Co-operation, 2000, Project to support the Agro-Ecological Zoning Programme (AEZ) in Namibia. Main Report, support the Agro-Ecological Zon
ICC, MAWRD \& AECI, Windhoek.

King, L.C., 1963, South African scenery, Hafner Publishing Company, New York.

Kizito, F., Dragila, M.I., Senè, M., Brooks, J.R., Meinzer, F.C., Diedhiou, I. et al., 2012, 'Hydraulic redistribution by two semi-arid shrub species: Implications for Sahelian agro-ecosystems', Journal of Arid Environments 83, 69-77. http://dx.doi. org/10.1016/j.jaridenv.2012.03.010

Laio, F., Porporato, A., Fernandez-Illescas, C.P. \& Rodriguez-Iturbe, I., 2001, 'Plants in water-controlled ecosystems: Active role in hydrologic processes and response to water stress. IV. Discussion of real cases', Advances in Water Resources 24, 745762. http://dx.doi.org/10.1016/\$0309-1708(01)00007-0

Laio, F., Porporato, A., Ridolfi, L. \& Rodriguez-Iturbe, I., 2001, 'Plants in watercontrolled ecosystems: Active role in hydrologic processes and response to water stress. II. Probabilistic soil moisture dynamics', Advances in Water Resources 24 707-723. http://dx.doi.org/10.1016/S0309-1708(01)00005-7

Le Roux, J., 2011, 'The effect of land use practices on the spatial and temporal characteristics of savanna fires in Namibia', PhD thesis, Faculty of Sciences, Universitätsbibliothek der Universität Erlangen-Nürnberg. 
Leser, H., 1972, 'Geoökologische Verhältnisse der Pflanzengesellschaften in den Savannen des Sandveldes um den Schwarzen Nossob und Epukiro [Geo-ecological relationships in the savannas of the Sandveld at the Black Nossob and Epukiro]", relationships in the
Dinteria 6, 1-44.

Mannheimer, C.A. \& Curtis, B.A. (eds.), 2009, Le Roux and Müller's field guide to the trees and shrubs of Namibia, Macmillan Education Namibia, Windhoek.

Martinez-Meza, E. \& Whitford, W.G., 1996, 'Stemflow, throughfall and channelization of stemflow by roots in three Chihuahuan desert shrubs', Journal of Arid Environments 32, 271-287. http://dx.doi.org/10.1006/jare.1996.0023

McCune, B., Grace, J.B. \& Urban, D.L., 2002, Analysis of ecological communities, MjM Software, Gleneden Beach.

Mendelsohn, J.M. \& el Obeid, S., 2002, Communal lands of eastern Namibia, RAISON, Windhoek.

Mendelsohn, J. \& el Obeid, S., 2003, Sand and water. A profile of the Kavango Region, Struik Publishers, Cape Town

Mendelsohn, J. \& Roberts, C., 1997, An environmental profile and atlas of Caprivi, Directorate of Environmental Affairs, Namibia.

Mendelsohn, J., Jarvis, A., Roberts, C. \& Robertson, T., 2002, Atlas of Namibia, David Phillips Publishers, Cape Town.

Merxmüller, H. (ed.), 1966, Prodromus zur Flora von SWA [Prodromus of the Flora of SWA], J. Cramer Verlag, Lehre.

Midgley, G., Hughes, G., Thuiller, W., Drew, G. \& Foden, W., 2005, 'Assessment of potential climate change impacts on Namibia's floristic diversity, ecosystem structure and function', Climate Change Research Group, South African National Biodiversity Institute for the Namibian National Biodiversity Programme, Directorate of Environmental Affairs, Cape Town.

Moustakas, A., Guenther, M., Wiegand, K., Mueller, K.-H., Ward, D., Meyer, K.M. e al., 2006, 'Long-term mortality patterns of the deep-rooted Acacia erioloba: The middle class shall die!', Journal of Vegetation Science 17, 473-480.

Mueller-Dombois, D. \& Ellenberg, H., 1974, Aims and methods of vegetation ecology, John Wiley \& Sons, New York.

Müller, M.A.N., 2007, Grasses of Namibia, 2nd edn., Ministry of Agriculture, Water and Forestry, Windhoek.

Mwitwa, J.P., Munthali, C.R.Y. \& Van Wyk, G., 2008, 'Heritability of shoot die-back and roo biomass in sixteen Pterocarpus angolensis (Fabaceae) half-sib families from Malawi, Namibia and Zambia', Southern Forests: A Journal of Forest Science 70, 221-226.

Namibia Meteorological Services, 1997, 'Monthly and annual rainfall normals for selected stations in Namibia which are used in the 10-Day Rainfall Bulletins', Working document from the Namibia Meteorological Services, Windhoek.

Namibian Agricultural Resources Information System (NARIS), 2001, 'NARIS Agro-Ecological Zoning Programme', Ministry of Agriculture, Water and Rural Development, Windhoek.

Noy-Meir, I., 1973, 'Desert ecosystems: Environment and producers', Annual Review of Ecology \& Systematics 54, 25-51. http://dx.doi.org/10.1146/annurev. es.04.110173.000325

Porporato, A., Laio, F., Ridolfi, L. \& Rodriguez-Iturbe, I., 2001, 'Plants in watercontrolled ecosystems: Active role in hydrologic processes and response to wate stress. III. Vegetation water stress', Advances in Water Resources 24, 725-744. http://dx.doi.org/10.1016/\$0309-1708(01)00006-9

Pressland, A.J., 1973, 'Rainfall partitioning by an arid woodland (Acacia aneura F. Muell.) in south-western Queensland', Australian Journal of Botany 21, 235-245. http://dx.doi.org/10.1071/BT9730235

Rodriguez-Iturbe, I., Porporato, A., Laio, F. \& Ridolfi, L., 2001, 'Plants in watercontrolled ecosystems: Active role in hydrologic processes and response to water stress. I. Scope and general outline', Advances in Water Resources 24, 695-705. http://dx.doi.org/10.1016/S0309-1708(01)00004-5
Savory, B.M., 1963, 'Site quality and tree root morphology in northern Rhodesia', Rhodesian Journal of Agricultural Research 1, 55-64.

Schulze, E.-D., Caldwell, M.M., Canadell, J., Mooney, H.A., Jackson, R.B., Parson, D. et al., 1998, 'Downward flux of water through roots (i.e. inverse hydraulic lift) in dry Kalahari sands', Oecologia 115, 460-462. http://dx.doi.org/10.1007/ s004420050541

Seghieri, J., Floret, C. \& Pontanier, R., 1995, 'Plant phenology in relation to water availability: Herbaceous and woody species in the savannas of northern Cameroon', Journal of Tropical Ecology 11, 237-254. http://dx.doi.org/10.1017/ S0266467400008713

Skarpe, C., 1996, 'Plant functional types and climate in a southern African savanna', Journal of Vegetation Science 7, 397-404. http://dx.doi.org/10.2307/3236283

Southern African Science Service Centre for Climate Change and Adaptive Land Use (SASSCAL) WeatherNet, 2012, Welcome to the weather stations of Angola, Botswana, Namibia and Zambia, viewed 30 October 2012, from http://www. biota-africa.org/weather/index.php

STATISTICA version 12, 2013, computer software, StatSoft Inc., Tulsa.

Strohbach, B.J., 2008, 'Mapping the major catchments of Namibia', Agricola 18, $63-73$.

Strohbach, B.J., 2014, 'Vegetation of the eastern communal conservancies in Namibia: I. Phytosociological descriptions', Koedoe 56(1), Art. \#1116, 18 pages. http:// dx.doi.org/10.4102/koedoe.v56i1.1116

Strohbach, B.J. \& Petersen, A., 2007, 'Vegetation of the central Kavango woodlands in Namibia: An example from the Mile 46 Livestock Development Centre', South African Journal of Botany 37, 391-401. http://dx.doi.org/10.1016/j sajb.2007.03.002

Strohbach, B.J., Strohbach, M., Kutuahuripa, J.T. \& Mouton, H.D., 2004, 'A reconnaissance survey of the landscapes, soils and vegetation of the eastern communal areas (Otjiozondjupa and Omaheke Regions), Namibia', Unpublished report for the Desert Research Foundation of Namibia and the Desert Margins Programme, National Botanical Research Institute, Windhoek.

Thomas, D.S.G., 1984, 'Ancient ergs of the former arid zones of Zimbabwe, Zambia and Angola', Transactions of the Institute of British Geographers 9, 75-88. http:// dx.doi.org/10.2307/621868

Thomas, D.S.G., Knight, M. \& Wiggs, G.F.S., 2005, 'Remobilization of southern African desert dune systems by twenty-first century global warming', Nature 435, 12181221. http://dx.doi.org/10.1038/nature03717

Timberlake, J.R. \& Calvert, G.M., 1993, 'Preliminary root atlas for Zimbabwe and Zambia', The Zimbabwe Bulletin of Forestry Research 10, Forestry Commission, Harare.

Tinley, K.L., 1982, 'The influence of soil moisture balance on ecosystem patterns in southern Africa', in B.J. Huntley \& B.H. Walker (eds.), Ecology of tropical savannas, Ecological Studies ser. 42, pp. 175-192, Springer Verlag, Berlin. http://dx.doi. org/10.1007/978-3-642-68786-0_9

Walter, H. \& Breckle, S.-W., 1984, Spezielle Ökologie der Tropischen und Subtropischen Zonen, Ökologie der Erde [Special ecology of the tropical and subtropical zones, Ecology of the Earth], vol. 2, Gustav Fischer Verlag, Stuttgart.

Walter, H., Harnickell, E. \& Mueller-Dombois, D., 1975, Climate-diagram maps 1-36, Springer Verlag, Berlin.

Warming, E., 1909, Oecology of plants. An introduction to the study of plantcommunities, Oxford University Press, London.

Werger, M.J.A. \& Ellenbroek, G.A., 1978, 'Leaf size and leaf consistence of a riverine forest formation along a climatic gradient', Oecologia 34, 297-308. http://dx.doi. org/10.1007/BF00344908

White, F., 1976, 'The underground forests of Africa: A preliminary review', Gardens' Bulletin Singapore 29, 57-71. 